\title{
STRATEGI MEDIA RELATIONS PT. PELABUHAN TANJUNG PRIOK DALAM MENANGGAPI KRISIS
}

\author{
Andi Refandi Febriyansyah, Maylanny Christin dan Ayub Ilfandy Imran \\ Universitas Telkom
}

\begin{abstract}
ABSTRAK
PT. Pelabuhan Indonesia II (Persero), salah satu Badan Usaha Milik Negara yang bergerak pada bidang kepelabuhanan ini memiliki permasalahan internal perusahaan yaitu Direktur Utama Richard Joost Lino yang terdakwa sebagai tersangka kasus korupsi mobile crane Pelindo II. Krisis mulai menjadi ancaman terhadap citra perusahaan PT. Pelabuhan Indonesia II (Persero) maupun anak perusahaannya, PT. Pelabuhan Tanjung Priok, yaitu sejak pemberitaan permasalahan ini tersebar luas di media cetak maupun elektronik pada bulan Agustus 2015 mengenai penggeledahan kantor Direktur Utama Pelindo II oleh Penyidik Bareskrim Polri. Metode yang digunakan pada penelitian ini yaitu metode kualitatif deskriptif dengan menggunakan teknik wawancara mendalam, observasi langsung penelitian di PT. Pelabuhan Tanjung Priok dan juga didukung oleh data dokumentasi dari perusahaan. Tujuan dari penelitian ini yaitu untuk mengetahui bagaimana strategi hubungan media PT. Pelabuhan Tanjung Priok dalam menanggapi krisis yang dihadapi oleh perusahaan induk. Berdasarkan hasil pengelolahan data, maka dapat diketahui bahwa kaitan antara kegiatan humas anak perusahaan dengan perusahaan induk yaitu saling mendukung dan membantu segala kegiatan yang dilakukan oleh humas perusahaan induk. Namun, pada saat terjadi krisis, pihak humas PT. Pelabuhan Tanjung Priok tidak ikut berkontribusi banyak dalam penanganan krisis melainkan hanya membantu dalam penyebaran informasi yang positif dan benar kepada media cetak maupun elektronik.
\end{abstract}

Kata-kata kunci: Hubungan masyarakat, PT. Pelabuhan Tanjung Priok, hubungan media, krisis, perusahaan induk

\section{MEDIA RELATIONS STRATEGY OF PT. PORT OF TANJUNG PRIOK IN ADDRESSING CRISIS}

\section{ABSTRACT}

PT. Pelabuhan Indonesia II (Persero) is one of the State-Owned Enterprises of the Republic of Indonesia which has been operating for Port Authority. This company is also been having the internal problem since August 2015 which the problem itself was all about Richard Joost Lino as the President Director of Pelindo II that was being accused by mobile crane's corruption. Therefore, the crisis was became a threat for the company since the news of the rummage by Bareskrim Polri to the President Director of Pelindo II's office and it was prevailed all around the electronic medias and conventional-or-printed medias. The method that has been utilized for this research is descriptive qualitative method, and applying some technique through in-depth interview technique, direct observation at PT. Pelabuhan Tanjung Priok and also supported by company's data documentations. Thus, the research is purposed to find out on how the crises has been responded by using the media relations' strategies by PT. Pelabuhan Tanjung Priok. As the result of this research and thence the author had obtained the relations between the Public Relations'Affiliation Company and Public Relations' Holding Company is to supporting each other whilst the crucial point and to back up each other's company programs. Nonetheless, when the crucial point was happened, PT. Pelabuhan Tanjung Priok's Public Relations didn't contribute much by solving the crises yet just helped to spreading the truly and positive information through electronic medias or printed medias.

Keywords: Public Relations, PT. Pelabuhan Tanjung Priok, Media Relations, Crisis, Holding Company

Korespondensi: Andi Refandi Febriyansyah, S.I.Kom. Program Studi Ilmu Komunikasi, Fakultas Komunikasi dan Bisnis, Universitas Telkom, Jln. Telekomunikasi No. 1, Bandung, Jawa Barat.Email: andirefandi@gmail.com 


\section{PENDAHULUAN}

Seorang praktisi public relations yang baik dapat dilihat ketika dia mampu melakukan crisis management yang merupakan suatu ancaman bagi citra atau reputasi perusahaan maupun organisasi. Krisis dapat dialami oleh banyak perusahaan atau organisasi, baik krisis yang muncul dari internal maupun eksternal perusahaan atau organisasi tersebut. Suatu krisis akan dapat menjadikan perusahaan atau organisasi menjadi lebih baik atau bahkan lebih buruk. Namun hal itu ialah bergantung pada bagaimana suatu manajemen perusahaan memahami dan kemudian menanggapi situasi tersebut dan juga tergantung pada sikap, pandangan dan tindakan yang diambil dalam menanggapi dan menghadapi krisis tersebut. Keberadaan suatu krisis yang muncul merupakan dapat dijadikan sebagai pedoman perusahaan untuk menjadi lebih baik daripada sebelumnya.

Setiap organisasi sangat punya peluang untuk mengalami krisis. Namun, hal yang perlu difokuskan adalah bagaimana cara perusahaan atau organisasi tersebut menyikapi krisis yang dihadapi. Dapat dilihat bahwa divisi public relations atau hubungan masyarakat merupakan peran yang sangat penting dalam menanggapi krisis.

Menurut Joseph R. Dominick (Morissan, 2010: 8), public relations mengimplementasikan kegiatannya pada tiga bidang kajian kerja yaitu: pertama,humasmemilikikaitaneratdenganopini publik. Dalam artian di satu sisi, praktisi humas berupaya untuk mempengaruhi publik agar memberikan opini yang positif bagi organisasi atau perusahaan. Namun, di sisi lain humas harus berupaya untuk mengumpulkan informasi dari khalayak, kemudian menginterpretasikan informasi tersebut dan melaporkannya kepada manajemen jika informasi tersebut memiliki pengaruh terhadap keputusan manajemen. Kemudian yang kedua yaitu humas memiliki kaitan erat dengan komunikasi. Dalam artian praktisi humas bertanggung jawab untuk menjelaskan tindakan perusahaan kepada khayalak yang berkepentingan dengan organisasi atau perusahaan. Dan yang terakhir yaitu humas merupakan suatu fungsi manajemen. Dalam artian humas berfungsi untuk membantu manajemen dalam menetapkan tujuan yang hendak dicapai serta menyesuaikan diri terhadap lingkungan yang berubah.

Untuk menjadi salah satu peran penting dari bagian manajemen perusahaan atau organisasi, public relations sejatinya akan selalu berkenaan pada beberapa aktivitas yang dilakukan oleh perusahaan, organisasi, industri, perserikatan, sosial maupun pemerintah untuk menciptakan, memelihara hubungan yang baik yang juga bermanfaat dengan tujuan untuk menyesuaikan dengan keadaan sekitar serta untuk perkenalan diri kepada masyarakat. Hal tersebut dilakukan agar dapat mencapai tujuan organisasi maupun perusahaan.

Seorangpraktisipublicrelations, umumnya memiliki peran penting untuk membentuk suatu pemahaman, nilai-nilai, perilaku dan sikap dari publik agar dapat sejalan dengan kebutuhan dan tujuan perusahaan maupun organisasi. Dari pesan-pesan tersebut, dapat langsung disampaikan atau dikomunikasikan melalui media massa atau media lain yang dapat disesuaikan dengan tujuan target sasaran. Dari seluruh hal yang harus dibiasakan oleh public relations, tugas terberat dari praktisi ini adalah mewujudkan hubungan yang harmonis antara perusahaan dengan publik melalui media yang positif seperti, public understanding (pengertian publik), public confidence (kepercayaan publik), public support (dukungan publik) dan public cooperation (kerja sama publik).

Media Relations menurut Philip Lesly (Saputra \& Nasrullah, 2011: 129) adalah hubungan dengan media komunikasi untuk melakukan publisitas atau merespon kepentingan media terhadap kepentingan organisasi. Media relations ditujukan untuk membina hubungan baik dengan publik ataupun dengan stakeholder organisasi adalah bagian dari kajian ilmu komunikasi yang memfokuskan perhatiannya. Menjalin hubungan dengan media merupakan salah satu cara untuk menjaga dan meningkatkan citra organisasi di mata stakeholder-nya. Public relations merupakan profesi yang senantiasa berhubungan dengan media atau wartawan. Memang dari sekian tugas public relations dalam sebuah perusahaan salah satunya adalah mengelola media atau lebih sering disebut dengan media relations.

Salah satu program yang menunjang keberhasilan publisitas yang dilakukan 
oleh public relations yaitu media relations. Dikarenakan media merupakan sarana yang sangat menunjang dan efisien untuk mengkomunikasikan segala informasi dan kepentingan perusahaan. Media relation yaitu selalu berhubungan dengan adanya pemberian informasi atau pemberian tanggapan pada media pemberitaan atas nama organisasi atau klien. Semakin besar atau banyaknya akses yang didapat oleh publik melalui media massa berkaitan dengan produksi maupun layanan yang diberikan oleh perusahaan, maka semakin besar dan banyaknya pula tingkat kepercayaan publik. Namun, ketika perusahaan dihadapkan pada kondisi krisis, media relations dijadikan sebagai salah satu program yang diutamakan untuk menyelesaikan masalah sebagai suatu solusi yang dibuat, karena media relations ini tidak hanya dijadikan sebagai program untuk publisitas pada kondisi normal saja, melainkan dijadikan sebagai alat untuk mengkomunikasikan informasi yang faktual mengenai krisis yang dihadapi tersebut.

Suatu peran profesi public relations pada suatu perusahaan maupun organisasi yaitu selalu terlibat dalam aktivitas manajemen dan hampir seringkali menghadapi situasi yang bertentangan ataucrucialpoint.Padasaatcrucialpoint tersebut, menurut Ludwig Suparmo dalam bukunya Crisis management \& Public Relations (2011: 30), peran seorang public relations specialist crisis merupakan yang sangat diandalkan dalam mengelola crisis management, karena peran public relations memiliki pengetahuan yang luas dan keterampilan yang bertindak sebagai konsultan atau penasehat kepada pemangku pemimpin perusahaan atau institusi, dapat secara efisien dan efektif membina hubungan komunikasi dan dapat menjelaskan kejadian dengan tepat dan tanggap (segera). Jika crucial point tersebut tidak langsung ditindak, dampak negatif dan kejadian buruk akan menimpa perusahaan seperti dapat mempengaruhi citra, dan juga akan berdampak negatif pada publik internal (perusahaan, investor, pemangku manajemen dan staf) dan publik eksternal (pemegang saham, pemasok, distributor, klien, konsumen, pemerintah dan media yang terkait dengan perusahaan tersebut).

Pada sisi lain, dari adanya crucial point tersebut dapat memunculkan sorotan langsung dari publik maupun media yang selalu menekan dan menampilkan informasi-informasi yang tidak akurat sehingga tidak adanya fakta yang ditampilkan dari masalah tersebut. Seperti yang telah diadaptasikan oleh Morissan dalam bukunya Manajemen Public Relations (2010: 171) yaitu Crisis Management merupakan upaya untuk meminimalisir faktor ketidakpastian dan faktor resiko, hingga demikian akan lebih mampu menampilkan sebanyak mungkin dari pada faktor kepastian nya.

Hal tersebut juga terjadi pada salah satu Badan Usaha Milik Negara yaitu PT. Pelabuhan Tanjung Priok yang merupakan salah satu anak perusahaan dari PT. Pelabuhan Indonesia II (Persero) yaitu pelayanan pemanduan dan penundaan kapal keluar masuk pelabuhan, oleh gerak kapal di dalam kolam sertajasa pemanduan dan penundaan dari satu pelabuhan ke pelabuhan lainnya dan juga kegiatan operasional pelabuhan yang dikoordinasikan oleh lembaga pemerintah yang disebut Port Authority. Krisis yang dialami oleh PT. Pelabuhan Indonesia II (Persero) atau Pelindo II yaitu muncul karena adanya pemberitaan kasus korupsi oleh Direktur Utama PT. Pelabuhan Indonesia II yaitu Richard Joost Lino atau yang biasa dipanggil R. J. Lino. Pemberitaan kasus terdakwa nya R. J. Lino yang diduga korupsi pengadaan 10 unit mobile crane di PT. Pelabuhan Indonesia II.

Berdasarkan data dan informasi yang diperoleh penulis dari website perusahaan (indonesiaport.co.id) bahwa Pelindo II telah melakukan proses pengadaan 10 mobile crane dengan anggaran sebesar Rp. 58.922.500.000, sesuai dengan mekanisme dan ketentuan yang berlaku, yaitu melalui dua kali pelelangan dan kemudian Pengadaan 10 unit dapat direalisasikan dengan harga sebesar Rp. 45.650.000.000 yang berarti $23 \%$ di bawah anggaran. PT. Pelabuhan Indonesia II (Persero) telah melakukan proses

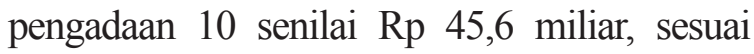
dengan mekanisme dan ketentuan yang berlaku, melalui dua kali pelelangan dengan total peserta 8 perusahaan lokal dan asing.

PT. Pelabuhan Indonesia II (Persero) telah melakukan proses pengadaan 10 sesuai SK Direksi PELINDO II tentang Prosedur dan Tata Cara Pengadaan Barang atau Jasa di Lingkungan PELINDO II. Dasar penggunaan SK Direksi bagi Pengadaan barang dan jasa di lingkungan perusahaan adalah mendasarkan pada PP 45 Tahun 2005 dan Peraturan Menteri 
BUMN No. 5 Tahun 2008.

Pengadaan dalam rangka meningkatkan produktivitas dalam hal kecepatan penanganan barang. Bahkan pengadaan 10 dilakukan melalui pelelangan dengan besaran anggaran Rp. 58,9 miliar. Setelah melalui proses penilaian dan negosiasi maka terealisasi sebesar Rp 45,6 miliar.

Penganggaran pengadaan crane tersebut ada dalam Rencana Kegiatan dan Anggaran Perusahaan (RKAP) 2011 seperti dijelaskan di atas. Adapun pengadaan dilakukan secara lelang terbuka, dimana dilakukan dua pelelangan. Berdasarkan RKAP (Rencana Kerja Anggaran Perusahaan) Tahun 2011 Nomor HK.56/1/3/ PI.II-11 bulan Januari 2011 bahwa hasil dari RKAP tersebut adalah:

Berdasarkan informasi dan data yang diperoleh penulis dari White Book IPC (2015) bahwa awalnya pengadaan direncanakan untuk Cabang Banten, Panjang, Palembang, Jambi, Teluk Bayur, Pontianak, Cirebon dan Bengkulu. Tetapi dalam perkembangan selanjutnya, alat ditempatkan dan digunakan di PT. Pelabuhan Tanjung Priok dengan pertimbangan bahwa PT. Pelabuhan Tanjung Priok sedang melakukan penataan kembali pola layanan di setiap terminalnya, dan alat dibutuhkan dalam penataan pola layanan dimaksud. Selain itu, alat dapat juga digunakan sebagai back-up alat utama.

Krisis yang terjadi di Pelindo II ini mulai termuat oleh media sejak adanya penggeledahan penyidik Bareskrim pada bulan Agustus 2015 di kantor Direktur Utama PT. Pelabuhan Indonesia II, R. J. Lino. Seperti yang dimuat pada salah satu media nasional yaitu Liputan6.com, bahwa Kapolri Jenderal Pol Badrodin Haiti memastikan penyidik Bareskrim Polri akan memeriksa Dirut Pelindo II R. J. Lino terkait dengan kasus korupsi proyek pengadaan mobile crane di Pelindo II. Penggeledahan kantor PT. Pelindo II di Pelabuhan Tanjung Priok dilakukan oleh Bareskrim Polri, pada Jumat 28 Agustus 2015. Dirtipideksus saat itu Brigjen Victor Simanjuntak yang mengatakan bahwa penggeledahan didasarkan atas dugaan adanya pengadaan mobile crane yang tidak sesuai aturan (RON/MUT, Liputan6.com: 2015). Kemudian kasus ini berlanjut dengan adanya tersangka lain atas kasus korupsi tersebut yaitu Ferialdy Noerlan sebagai Direktur Operasi dan Teknik PT. Pelabuhan Indonesia II (Persero) pada tanggal 28 Agustus 2015 (Huda, 2015).

Pada hari Jumat tanggal 18 Desember 2016, Komisi Pemberantasan Korupsi (KPK) menetapkan R. J. Lino sebagai tersangka korupsi korupsi pengadaan Quay Container Crane (QCC) di PT. Pelabuhan Indonesia II (Persero) tahun anggaran 2010, yang diduga dilakukan mantan Direktur Utama PT Pelindo 11 Richard Joost Lino yaitu disangka telah melanggar pasal 2 ayat 1 dan atau pasal 3 Undang-Undang Nomor 31 Tahun 1999 sebagaimana telah diubah dengan Undang-Undang Nomor 20 Tahun 2001 Juncto Pasal 55 ayat 1 ke-1 KUH Pidana tentang Pemberantasan Tindak Pidana Korupsi. (Putra, 2016).

Kemudian, KPK juga memeriksa lebih lanjut Dian (Mantan Direktur Keuangan PT. Pelabuhan Indonesia II (Persero)), Moch. Soleh (Asisten Manajer Teknik Mesin dan Instalasi Listrik Cabang Pontianak Pelindo II), Dedi Iskandar (Asisten Senior Manajer (ASM) Properti II Subdit Perencanaan dan Pengembangan Bisnis II Pelindo II) dan Mashudi Sanyoto (Direktur Teknik dan Operasi PT Jasa Peralatan Pelabuhan Indonesia (JPPI). Menurut Yuyuk Andriati yaitu sebagai Pelaksana Harian Kepala Biro Humas KPK, Dian akan diperiksa untuk tersangka R. J. Lino dan untuk Moch. Soleh, Dedi Iskandar serta Mashudi Sanyoto akan diperiksa sebagai saksi. Juga masih akan ada saksi-saksi lainnya yang akan diperiksa lebih lanjut (Rakhmatulloh: 2016).

Dengan demikian, peranan public relations PT. Pelabuhan Tanjung Priok selaku anak perusahaan PT. Pelabuhan Indonesia II (Persero) mengenai krisis yang terjadi pada Holding Company atau PT. Pelabuhan Indonesia II (Persero) tersebut merupakan penting dan sangat menguntungkan bagi perusahaan, karena kontribusi anak perusahaan maupun anak cabang sangat dibutuhkan dalam suatu permasalahan perusahaan. Hal itu juga dapat saling mendukung dan membantu serta mempertahankan reputasi perusahaan menjadi lebih baik dan positif jika terjadinya suatu krisis terutama krisis yang dialami PT. Pelabuhan Indonesia II (Persero) mengenai pemberitaan kasus korupsi R. J. Lino ini. Oleh karena itu, dengan adanya kasus tersebut, maka penulis akan meninjau lebih lanjut mengenai strategi media relations apa saja yang telah dilakukan oleh PT. Pelabuhan Tanjung Priok 
dalam menanggapi krisis yang dihadapi oleh PT. Pelabuhan Indonesia II (Persero) sebagai holding company tersebut.

\section{METODE PENELITIAN}

Metode yang digunakan penulis dalam melakukan penelitian ini yaitu dengan melalui pendekatan kualitatif. Data yang dikumpulkan penelitian dengan pendekatan kualitatif bukan berupa angka-angka melainkan data tersebut berasal dari naskah wawancara, catatan lapangan, dokumen pribadi, catatan, memo dan dokumen resmi lainnya. Selain itu juga, dengan penelitian kualitatif, penulis berusaha membangun makna mengenai suatu fenomena berdasarkan pandangan-pandangan dari para narasumber. Penulis menggunakan paradigma konstruktivis dikarenakan penelitian ini ber-tujuan untuk menjabarkan suatu strategi media relations yang dilakukan oleh public relations PT. Pelabuhan Tanjung Priok dalam menanggapi krisis yang dihadapi PT. Pelabuhan Indonesia II (Persero) sebagai holding company.

Jenis penelitian deskriptif kualitatif yang penulis gunakan dalam penelitian ini adalah studi kasus. Menurut Yin (Mukhtar, 2013: 35) yang dimaksud dengan studi kasus adalah salah satu metode penelitian ilmu sosial. Metode penelitian ini sangat cocok untuk digunakan manakala seorang penulis ingin mengungkap sesuatu dengan bertolak pada pertanyaan "How atau Why".

\section{HASIL DAN PEMBAHASAN}

Frank Jefkins (dalam Yadin, 2003: 10) mengemukakan bahwa public relations merupakan bentuk komunikasi yang terencana, baik itu ke dalam, maupun ke luar, antara suatu organisasi dengan semua khalayaknya dalam rangka mencapai tujuan-tujuan spesifik yang berlandaskan pada saling pengertian. Sedangkan J. H. Wright mengemukakan bahwa public relations yang modern merupakan suatu rencana tentang kebijaksanaan dan kepemimpinan yang akan menanamkan kepercayaan publik dan menambah pengertian mereka (Saputra \& Nasrullah, 2011: 3).

Strategi aksi ditujukan untuk melayani kepentingan bersama, yaitu perusahaan dan publiknya. Strategi aksi didasarkan pengetahuan bagaimana kebijakan perusahaan, prosedur aksi dan output lainnya memberikan kontribusi terhadap masalah public relations. Suatu pemahaman yang menyeluruh atas situasi bermasalah sangat penting untuk merancang strategi aksi. Strategi aksi juga terfokus pada upaya melakukan penyesuaian (adjustment) dan adaptasi pada organisasi atau perusahaan. Menurut Firsan Nova, strategi public relations terdiri dari: (1) Publication. Setiap fungsi dan tugas public relations adalah menyelenggarakan publikasi atau menyebarluaskan informasi melalui berbagai media mengenai kegiatan dan aktivitas perusahaan yang layak diketahui oleh publik. Dalam hal ini tugas public relations adalah menciptakan berita untuk mencari publisitas melalui kerjasama dengan pihak media (pers atau wartawan) dengan tujuan menguntungkan citra perusahaan yang diwakilkannya. (2) Event. Tugas merancang event bertujuan untuk memperkenalkan produk dan layanan perusahaan, mendekatkan diri ke publik dan lebih jauh lagi dapat mempengaruhi opini publik. (3) News. Berupaya menciptakan berita melalui press release, news letter, bulletin, dll. oleh karena itu seorang public relations harus mempunyai kemampuan menulis yang baik untuk men-ciptakan publisitas, (4) Community Involvement. Keterlibatan tugas sehari hari seorang public relations adalah mengadakan kontak sosial dengan kelompok masyarakat tertentu guna menjaga hubungan baik (community relations and human relations) antara masyarakat dengan perusahaan yang diwakilinya, (5) Inform or Built Image. Salah satu fungsi utama dari public relations, yaitu memberikan informasi kepada publik atau menarik perhatian, sehingga diharap-kan dapat memperoleh tanggapan berupa citra positif, (6) Lobbying and Negotiation. Keterampilan untuk melobi melalui pende-katan pribadi dan kemampuan bernegosiasi sangat diperlukan bagi seorang public relations. Tujuan lobi adalah untuk meraih kese-pakatan (deal), atau memperoleh dukungan dari individu dan lembaga yang berpengaruh terhadap kelangsungan bisnis perusahaan, dan (7) Social Responsibility. Memiliki tanggung jawab sosial dalam aktivitas public relations yaitu menunjukkan bahwa perusahaan memiliki kepedulian ter-hadap masyarakat. Hal ini sangat penting untuk meningkatkan citra perusahaan di mata publik. 
Bentuknya beragam, seperti kegiatan peduli banjir, memberikan beasiswa, santunan anak yatim, pengobatan gratis, dan masih banyak kegiatan lainnya (Nova, 2011: 54).

Langkah-langkah yang dilakukan oleh humas PT. Pelabuhan Tanjung Priok maupun Holding Company atau PT. Pelabuhan Indonesia II (Persero) yaitu diantaranya adalah:

Pertama yaitu dengan mengidentifikasi permasalahan sebelumnyasepertimengumpulkan internal (para karyawan dan direksi) perusahaan terlebih dahulu ke Auditorium perusahaan untuk mengantisipasi suatu langkah yang salah yang dilakukan oleh pihak internal atau karyawan perusahaan dan juga direksi perusahaan langsung ikut turun dalam memberi informasi kepada para karyawan internal perusahaan untuk tidak terprovokasi oleh pihak luar yang terkait dengan permasalahan tersebut, dalam artian yaitu direksi mengarahkan langsung bagaimana langkah untuk mengantisipasi permasalahan yang terjadi pada perusahaan agar tidak menjadi semakin rumit.

Kemudian langkah yang diambil oleh perusahaan yaitu dengan menahan statementstatement yang dapat berdampak buruk kepada perusahaan, karena menurut para informan penelitian ini yaitu bahwa krisis atau permasalahan yang terjadi tersebut merupakan suatu permasalahan politik yang terjadi pada Top Management Holding Company. Langkah selanjutnya yaitu menanggulangi pemberitaanpemberitaan negatif dari media dengan cara pihak Humas PT. Pelabuhan Indonesia II (Persero) maupun PT. Pelabuhan Tanjung Priok selalu memantau media atau monitoring media dan kemudian mengevaluasi hasil pemberitaan tersebut dan kegiatan tersebut juga merupakan salah satu kegiatan rutin pihak humas perusahaan.

Tahap berikutnya, Humas mengeluarkan press release ke media cetak maupun elektronik. Selain langkah-langkah tersebut, pihak Humas PT. Pelabuhan Tanjung Priok juga mengadakan beberapa event perlombaan maupun kegiatan CSR (Corporate Social Responsibilty) demi mempertahankan kontribusi kepada masyarakat sekitar yang telah dibangun selama ini maupun citra positif perusahaan di mata Masyarakat sekitar Indonesia Port Company tersebut. Kegiatan CSR yang terhitung mulai tahun 2016 tersebut yaitu diantaranya adalah:

PROKASIH atau Aksi Bersih Lingkungan yang langsung diikuti Masyarakat Kelurahan Lagoa RW. 03 Kecamatan Koja Jakarta Utara pada tanggal 17 Januari 2016 yaitu merupakan tindak lanjut kegiatan CSR pada tanggal 10 Januari 2015. Kegiatan dengan tema "bersihbersih kampung kita" tersebut terfokus dalam rangka untuk membersihkan aliran sungai di daerah RW. 04 Lagoa yang padat dengan penduduk. Lurah Lagoa, Indria Hilmi juga langsung turun berpartisipasi langsung dalam kegiatan CSR PT. Pelabuhan Tanjung Priok dan menyampaikan bahwa aksi yang dilakukan perusahaan seperti ini perlu dilakukan secara rutin agar lingkungan Kelurahan Lagoa khususnya di sekitar Pasar dan wilayah Jakarta Utara yang padat penduduk menjadi lebih bersih dan terhindar dari banjir.

Kegiatan CSR berikutnya yaitu kegiatan Seminar Lokakarya dengan tema "mewujudkan sekolah peduli dan berbudaya lingkungan di wilayah Kelurahan Koja dan Kelurahan Lagoa, Kecamatan Koja, Jakarta Utara”. Kegiatan tersebut diadakan pada hari Sabtu tanggal 16 Januari 2016 di Aula Kantor Kecamatan Koja, Jakarta Utara dengan jumlah peserta sekitar 50 perwakilan dari sekolah-sekolah di setiap tingkatan (TK, SD, SLTP maupun SLTA) wilayah Kelurahan Koja dan Lagoa, Jakarta Utara. Seminar tersebut merupakan upaya kerjasama PT. Pelabuhan Tanjung Priok dengan Kecamatan Koja, Badan Lingkungan Hidup Jakarta Utara, Dinas Pendidikan Jakarta Utara dan Detara Foundation.

Kegiatan CSR PT. Pelabuhan Tanjung Priok berikutnya yaitu pelatihan warga Lagoa dan Koja Jakarta Utara dalam mengolah sampah, kegiatan tersebut dilakukan pada tanggal 13 Februari 2016. Kegiatan dilakukan dalam rangka meningkatkan kesadaran Masyarakat dalam pengelolaan sampah sekaligus dalam upaya mengurangi dampak banjir. PT. Pelabuhan Tanjung Priok bersama Local Champion yang terpilih dari warga Kelurahan Lagoa dan Koja Jakarta Utara, melakukan kampanye lingkungan melalui kegiatan "Pelatihan Pengelolahan Sampah". Kegiatan-kegiatan yang dilakukan oleh CSR PT. Pelabuhan Tanjung Priok tersebut diupayakan demi suatu citra yang positif secara konsekuen di mata publik.

Selain itu juga langkah berikut yang dilakukan oleh PT. Pelabuhan Tanjung Priok 
terhadap permasalahan yang muncul di Holding Company tersebut juga selalu didukung oleh pihak seluruh anak perusahaan maupun anak cabang yang salah satunya adalah PT. Pelabuhan Tanjung Priok demi kehidupan perusahaan ke arah yang lebih baik. Jadi selama krisis terjadi di IPC, PT. Pelabuhan Tanjung Priok, langkahlangkah yang dilakukan yaitu dengan selalu melakukan keterbukaan informasi kepada publik demi memperbaiki citra perusahaan. Salah satunya yaitu peluncuran press release mengenai Program Tol Laut di PT. Pelabuhan Tanjung Priok yang langsung dibuka oleh Menteri Perhubungan dan Menteri Perdagangan. Hal itu dilakukan demi keterbukaan kepada publik maupun Negara agar tidak terjadi kesalah pahaman yang berulang mengenai seluruh kegiatan yang dilakukan oleh Indonesia Port Company tersebut. Selain itu juga Humas PT. Pelabuhan Tanjung Priok maupun PT. Pelabuhan Indonesia II (Persero) berperan dalam melakukan langkah-langkah selanjutnya yaitu dengan memanage internal perusahaan terlebih dahulu dalam menanggapi krisis dan melakukan monitoring berita yang selanjutnya disimpulkan beritanya dari media tersebut.

Strategi media relations merupakan sekumpulan kebijakan dan taktik yang sudah ditetapkan untuk mencapai tujuan kegiatan media relations khususnya, dan public relations yang tentunya sebagai peranan yang diacukan pada tujuan perusahaan. Tujuan yang hendak dicapai melalui kegiatan media relations selalu dikelompokkan menjadi tiga kategori, yaitu diantaranya: (1) Meningkatkan kesadaran, seperti kesadaran merek (brand-awareness) pada publik, (2) Mengubah sikap, mengubah sikap dari anti menjadi netral dan dari netral menjadi mendukung terhadap tindakan yang dilakukan perusahaan atau organisasi, dan (3) Mendorong tindakan, mendorong untuk mendukung kebijakan proses produksi yang ramah lingkungan yang ditujukan perusahaan atau organisasi.

Strategi itu sendiri didefinisikan sebagai metode penggunaan unsur-unsur strategis untuk mencapai tujuan-tujuan spesifik yang telah ditetapkan. Dalam manajemen krisis, terdapat tiga macam strategi yang biasa diterapkan dalam menanggulangi krisis, yaitu diantaranya adalah sebagai berikut (Saputra \& Nasrullah, 2011: 155):

Pertama, Defensive Strategy (Strategi
Defensif). Strategi bertahan yang dilakukan oleh perusahaan ketika menghadapi media. Pilihan strategi ini bias dilakukan apabila perusahaan dan pelaksana media relations merasa memiliki keyakinan penuh bahwa tidak ada kesalahan prosedural ataupun legal yang dilakukan oleh perusahaan. Adapun langkah-langkah yang dilakukan dalam strategi ini yaitu dengan mengulur waktu, tidak melakukan apa-apa dan membentengi diri dengan kuat.

Pada strategi pertama yaitu strategi defensif yang dilakukan oleh Humas PT. Pelabuhan Tanjung Priok dalam menanggapi krisis yang terjadi pada PT. Pelabuhan Indonesia II (Persero) yaitu dengan tetap menunjukkan kegiatan-kegiatan positif kepada publik dan memberikan informasi kepada media bahwa PT. Pelabuhan Tanjung Priok merupakan tidak identik dengan Holding Company agar citra PT. Pelabuhan Tanjung Priok tidak terpengaruh menjadi negatif karena adanya berita tersebut.

Salah satu contoh kegiatan hubungan media yang dilakukan oleh PT. Pelabuhan Tanjung Priok dan PT. Pelabuhan Indonesia II (Persero) dalam menanggapi krisis ini yaitu dengan mengadakan event omba Foto yang bertemakan The Art of Modern Priok dan bekerja sama dengan salah satu media nasional yaitu Media Indonesia. Kegiatan ini dilakukan demi memberi edukasi kepada publik bahwa PT. Pelabuhan Tanjung Priok merupakan salah satu anak perusahaan induk perusahaan PT. Pelabuhan Indonesia II (Persero) dan juga dijadikan sebagai acuan atau benteng diri yang kuat untuk perusahaan tetap memiliki nilai positif dari adanya kasus yang dialami Holding Company tersebut.

Dengan demikian, kegiatan pada strategi ini yang dilakukan oleh PT. Pelabuhan Tanjung Priok yaitu tetap membenarkan bahwa PT. Pelabuhan Tanjung Priok tidak terkait dengan permasalahan yang dihadapi oleh Holding Company tersebut. Selama krisis berlangsung pun strategi yang dibangun oleh PT. Pelabuhan Tanjung Priok yaitu tetap mendidik khalayak mengenai perbedaan PT. Pelabuhan Indonesia II (Persero) dengan PT. Pelabuhan Tanjung Priok itu sendiri. Namun PT. Pelabuhan Tanjung Priok yang merupakan sebagai salah satu anak perusahaan Holding Company tersebut tetap bertindak untuk mensupport segala tindakan dan arahan yang selama ini diperintahkan oleh 
Holding Company, baik selama krisis terjadi maupun tidak terjadi. Komunikasi yang terjadi antara Holding Company dan anak perusahaan terutama PT. Pelabuhan Tanjung Priok tetap berjalan dengan lancar dan sesuai aturan dan ketentuan yang telah digariskan oleh perusahaan.

Kedua, Adaptive Strategy (Strategi Adaptif). Pilihan strategi adaptif bagi perusahaan yang mengalami krisis yang tidak lepas dari kesalahan dan kelalaian perusahaan. Kesalahan ini menyebabkan perusahaan tidak mungkin bersikap defensif. Melainkan perlu berani mengakui kesalahan dan mengambil resiko dengan melakukan perubahan. Langkah-langkah yang mencakup hal-hal yang lebih luas sebagai berikut: mengubah kebijakan, modifikasi operasional, kompromi dan meluruskan citra.

Kemudian pada tingkatan krisis yang terjadi oleh PT. Pelabuhan Indonesia II (Persero), pihak perusahaan maupun humas melakukan strategi yaitu dengan tidak menutupi melainkan mengedepankan hal yang positif kepada media dan yang kemudian juga kasus ini merupakan yang langsung ditangani ranah hukum setelah tersangka masalah ini ditetapkan. Salah satu tindakan dalam melakukan strategi adaptif ini yaitu perusahaan mengedepankan informasi positif kepada publik dengan mengeluarkan press release di official website perusahaan (indonesiaport.co.id) mengenai IPC meraih gelar Good Performance Company Dalam Assesmen Kriteria Penilaian Kinerja Unggul dalam agenda akhir tahun 2015 pada 21-27 November 2015. Dari hasil pelaksanaan assesmen IPC mendapatkan skor 479,25 yang menempatkan perusahaan dalam kategori "Good Performance Company".

Namun pada strategi adaptif ini pun PT. Pelabuhan Tanjung Priok tidak melakukan tindakan defensive melainkan menahan statement-statement dari internal karyawan perusahaan agar informasi yang dikeluarkan tidak lagi membuat masalah menjadi rumit maupun bertambah lebar. Selain itu pada langkah dalam melakukan strategi ini juga PT. Pelabuhan Indonesia II (Persero) melakukan perubahan struktural direksi yang merupakan pihak yang tersangkut dengan masalah tersebut telah digantikan oleh Pelaksana Tugas Jabatan atau PLT yaitu Dede R. Martin, dan pergantian tersebut dilakukan oleh Menteri Badan Usaha Milik Negara yaitu Rini Soemarno.
Ketiga, Dynamic Strategy (Strategi Dinamik). Sangat cocok untuk perusahaan yang mengalami komunikasi krisis tingkat kronis atau yang dihadapi perusahaan sudah terlampau serius, sehingga perlu digunakan langkahlangkah khusus. Strategi memerlukan banyak unsur-unsur strategis, karena itu dianggap sebagai strategi yang mahal. Perusahaan sebaiknya menilai secara akurat tingkat krisis yang sedang dialami sebelum memilih strategi dinamis ini agar tidak terlalu menekan biaya yang cukup banyak.

Beberapa contoh tindakan pada strategi dinamis ini seperti, marger dengan perusahaan lain, mengundang investor baru, atau menarik produk lama dan meluncurkan produk baru ke pasar. Dan juga dapat melalui, pelaksana media relations merancang kegiatan kampanye ke publik internal dan eksternal, mengatur dan menyelenggarakan lobbying ke pejabat-pejabat media tertentu, mengadakan kerjasama dengan berbagai media dan perusahaan periklanan, hingga merancang aktivitas-aktivitas sosial. Pada strategi ini merupakan sudah bersifat agak makro dan dapat mengakibatkan berubahnya karakter perusahaan. Pilihannya adalah: Marger dan akuisisi, investasi baru, menjual saham, meluncurkan produk baru atau menarik peredaran produk lama, dan melempar isu baru untuk mengalihkan perhatian.

Namun pada strategi dinamis ini yaitu perusahaan telah mencapai titik akhir yang merupakan permasalahan pada individu tersebut tidak lagi menjabat di PT. Pelabuhan Indonesia II (Persero) dan bahwa pada strategi hubungan media yang dilakukan oleh perusahaan baik dari PT. Pelabuhan Tanjung Priok maupun Holding Company, tim humas melakukan strategi khusus yang selama ini dibangun yaitu dengan berhubungan baik dengan media secara personal atau antar pribadi dengan wartawan secara langsung, hal tersebut dilakukan demi kelancaran seluruh kegiatan dengan media baik untuk penyebaran informasi maupun klarifikasi permasalahan.

Setelah krisis yang terjadi pada Top Management tersebut, perusahaan tidak lagi menjadi center of news dan tim Humas PT. Pelabuhan Tanjung Priok pun tetap menjaga statement dan lebih tidak menutupi informasi karena permasalahan yang terjadi sudah merupakan ranah hukum. Selain itu strategi 
yang dilakukan oleh perusahaan dan tim humas yaitu rencana melakukan media gathering dan membuat lebih banyak kontribusi perusahaan kepada masyarakat yang selama ini telah dibangun secara baik, konsisten dan kontinu.

Demikian setelah adanya krisis atau permasalahan yang terjadi pada induk perusahaan tersebut, maka hubungan media dengan perusahaan tetap berjalan dengan baik demi penyampaian informasi yang positif oleh media kepada publik mengenai Indonesia Port Company itu sendiri. Berikut salah satu media yang memberikan positive point terhadap perusahaan setelah adanya pemberitaan yang terfokus pada Direktur Utama R. J. Lino, yaitu media nasional Warta Kota Tribun News memberitakan kegiatan Ekspor Impor Pelabuhan Tanjung Priok berjalan lancar ataupun normal.

Pada Tahapan Krisis, pemimpin harus dapat belajar dari setiap krisis yang terjadi. Cara mengidentifikasi siklus krisis, dimulai dengan persiapan menghadapi krisis (preparedness for crises), penyelesaian krisis (crisis resolution), mengambil pelajaran dari krisis (consolidation of learning), mengkomunikasikan kepada publik (communication for change), dan berkomitmen untuk melakukan perbaikan di masa datang (initiation of change).

Tahapan-tahapan krisis yang diutarakan oleh Nova (2011: 95), terdapat lima tahapan dalam siklus hidup krisis yang harus dikenali dan dipahami, yaitu diantaranya adalah:

Pertama, Tahap Pre-Crisis (Sebelum Krisis). Pre-crisis adalah kondisi sebelum sebuah krisis muncul. Benih krisis juga sudah ada sehingga jika muncul suatu kesalahan yang kecil saja, krisis dapat terjadi. Benih yang mulai tumbuh pada tahap ini biasanya tidak diperhatikan karena beberapa aspek dalam perusahaan memang penuh resiko. Selain itu, perusahaan tidak mempunyai perencanaan menghadapi krisis.

Pada tahapan sebelum krisis yang dialami oleh PT. Pelabuhan Indonesia II (Persero), kondisi yang ada di Indonesia Port Company tetap berjalan dengan normal. Namun saat krisis ini mulai menjadi center of news, media langsung mencari tahu kondisi di perusahaan maupun kondisi mobile crane tersebut dengan mendatangi langsung lapangan PT. Pelabuhan Tanjung Priok yang merupakan tempat penyimpanan atau penumpukan mobile crane tersebut. Pada tahap sebelum krisis ini terjadi pun sudah banyak isu yang menimpa pada perusahaan dari pihak eksternal (media dan publik). Oleh karena itu internal perusahaan yaitu para karyawan selalu diminta atau dihimbau untuk tetap fokus bekerja dan seoptimal mungkin dalam melakukan kegiatan ataupun aktivitas dalam bertugas.

Pada tahap ini, peran direktur utama PT. Pelabuhan Tanjung Priok yaitu untuk langsung menyampaikan kepada internal perusahaan atau karyawan perusahaan agar tidak mengeluarkan opini atau pernyataan yang dapat memperkeruh suasana, melainkan agar tetap fokus dan bekerja secara profesional, karena selama permasalahan ini terjadi, tidak ada pengaruh buruk terhadap kegiatan operasional pelabuhan maupun kinerja karyawam. Dengan demikian, para karyawan dihimbau untuk bekerja seoptimal mungkin demi mencapai tujuan visi-misi perusahaan.

Kedua, Tahap Warning (Peringatan). Tahap ini dianggap sebagai salah satu tahap yang paling penting dalam daur hidup krisis. Di dalamnya, suatu masalah untuk pertama kalinya dikenali, dapat dipecahkan dan diakhiri selamanya, atau dibiarkan berkembang menuju kepada kerusakan yang menyeluruh. Krisis dapat dengan mudah muncul pada tahap ini karena ketakutan menghadapi badai atau masalah dan menganggapnya tidak ada. Reaksi yang umum terjadi pada tahap ini adalah kaget atau menyangkal dan pura-pura merasa aman.

Kemudian pada tahapan krisis menjadi suatu peringatan bagi perusahaan, kondisi yang terjadi pada IPC pada tahap seperti ini yaitu mengatur terlebih dahulu internal perusahaan dan tetap fokus bekerja secara profesional. Selain itu juga untuk kegiatan hubungan dengan media terkait dengan pemberitaan permasalahan ini, dan perusahaan sebisa mungkin untuk memberikan informasi apa adanya dan tidak ditutupi, juga para internal perusahaan yaitu para karyawan yang bekerja di perusahaan diminta agar menjaga statement di sosial media demi menghindari adanya kesalahpahaman kepada pihak eksternal (media maupun publik). Hal tersebut juga dilakukan untuk menjaga citra baik perusahaan dimata publik maupun investor perusahaan.

Selain itu juga perusahaan mengeluarkan Brief Book (2015) yang berisikan mengenai 
beberapa permasalahan yang selama ini terjadi di Indonesia Port Company atau PT. Pelabuhan Indonesia II (Persero) dan seluruh anak cabang maupun anak perusahaannya. Hal tersebut dilakukan agar menghindari kesalah pahaman yang terulang dikemudian hari dan publik maupun pihak-pihak yang terkait dengan perusahaan (stakeholder maupun investor) dapat secara langsung melihat kebenaran yang dirangkum dalam Brief Book (2015) perusahaan tersebut.

Ketiga, Tahap Acute Crisis (Akut). Pada tahap ini krisis mulai terbentuk dan media juga publik mulai mengetahui adanya masalah. Jika krisis sudah mencapai pada tahap ini, perusahaan tidak dapat berdiam diri karena sudah mulai menimbulkan kerugian. Saat inilah berbagai dokumen dan modul untuk menghadapi krisis harus dikeluarkan dan digunakan. Saat-saat seperti ini dapat diketahui apakah para staf telah dibekali pengetahuan mengenai manajemen krisis atau tidak. Jika tidak, maka sudah terlambat bagi manajemen untuk memulainya dan menyelesaikan masalahnya.

Selain darikedua tahapan krisisyang terjadi di PT. Pelabuhan Indonesia II (Persero) tersebut. Maka pada tahapan krisis akut yang terjadi di perusahaan, terdapat perubahan struktural organisasi yaitu yang merupakan Direktur Utama PT. Pelabuhan Indonesia II (Persero) digantikan oleh Pelaksana Tugas Jabatan atau PLT yaitu Dede R. Martin, dan pergantian tersebut dilakukan oleh Menteri Badan Usaha Milik Negara yaitu Rini Soemarno. Demikian pemberitaan yang dibuat oleh media pada tahap ini merupakan pemberitaan yang berfokus pada pergantian direksi PT. Pelabuhan Indonesia II (Persero) tersebut.

Namun sebenarnya pada tahapan ini yaitu perusahaan tidak lagi khawatir akan keberlangsungan hidup perusahaan karena selama krisis terjadi, proses kegiatan operasional tidak berdampak sama sekali, namun yang selama ini di khawatirkan adalah adanya krisis pencitraan yang tidak diharapkan oleh perusahaan. Karena pemberitaan ini sudah menemukan titik akhir dari masalah tersebut yaitu tersangkanya Dirut PT. Pelabuhan Indonesia II (Persero) pada kasus korupsi mobile crane tersebut.

Keempat, Tahap Clean-Up (Pembersihan).
Saat masalah melewati tahap warning tanpa diselesaikan maka kerusakan perusahaan mulai timbul. Inilah waktunya untuk memulihkan perusahaan dari kerugian atau setidaknya menyelamatkan apa saja yang tersisa, baik sisa produk (jika dapat diaplikasikan), reputasi, citra perusahaan, kinerja, dan lini produksi.

Setelah melewati tahap krusial permasalahan yang terjadi di PT. Pelabuhan Indonesia II (Persero) atau IPC, maka perusahaan juga melihat pada tahap pembersihan pemberitaan ini. Pada tahap ini, tim humas PT. Pelabuhan Tanjung Priok mengeluarkan press release dalam bentuk cetak kepada Forum Wartawan Maritim Indonesia dan dimuat langsung di official website perusahaan (indonesiaport. co.id), karena pembentukan forum dan pengeluaran press release ini dilakukan maupun ditujukan langsung kepada pihak-pihak yang terkait langsung dengan perusahaan khususnya di bidang kemaritiman. Adapun isi dari press release setelah terjadinya permasalahan yang dihadapi perusahaan yaitu pergantian Dewan Komisiaris PT. Pelabuhan Indonesia II (Persero) yang dilakukan pada hari Selasa tanggal 1 Maret 2016 dan langsung ditetapkan oleh Menteri BUMN dengan Nomer SK-40/ MBU/03/2016 tanggal 1 Maret 2016.

Terakhir, Tahap Post-Crisis (Sesudah Krisis). Inilah tahap yang telah disebutkan sebelumnya, yakni perusahaan seharusnya bereaksi pada suatu krisis muncul tahap warning. Jika sejak awal tidak dihentikan, krisis akan terjadi. Jika perusahaan memenangkan kembali kepercayaan publik dan beroperasi kembali dengan normal, maka secara formal dapat dikatakan krisis telah berakhir.

Pada tahap terakhir yaitu tahap setelah krisis yang terjadi pada PT. Pelabuhan Indonesia II (Persero) merupakan pemberitaan di media yaitu pers tidak lagi memusatkan objek tempat atau perusahaan secara langsung melainkan tertuju kepada tersangka yang terkait permasalahan tersebut yaitu mantan Direktur Utama PT. Pelabuhan Indonesia II (Persero), R. J. Lino. Kemudian, perusahaan pun tidak mengambil tindakan apapun atas permasalahan tersebut melainkan setelah krisis itu terjadi pada Top Management PT. Pelabuhan Indonesia II (Persero) yaitu terdapat pergantian direksi dengan PLT atau Pelaksana Tugas Jabatan. Oleh karena itu pemberitaan kasus tersebut bukan 
lagi suatu ancaman bagi perusahaan karena kasus tersebut sudah masuk ke ranah hukum yang merupakan perusahaan tidak dapat berbuat apa-apa selain memperbaiki citra dengan cara bekerja optimal dan profesional sesuai visi-misi perusahaan selama ini.

Kegiatan yang dilakukan oleh Humas PT. Pelabuhan Indonesia II (Persero) dalam tahap ini yaitu mengeluarkan media release yang merupakan sinergi keterbukaan dengan publik maupun pemerintah mengenai kegiatan maupun tindakan yang dilakukan oleh IPC kedepannya. Isi dari media release yang dikeluarkan oleh IPC tersebut yaitu mengenai penandatanganan Nota Kesepakatan atau MOU dan perjanjian induk dengan delapan BUMN dalam rangka integrasi logistikmaritim untuk akselerasi konektivitas nasional dan langsung disaksikan oleh Menteri BUMN, Rini Sumarno di Kantor Kementrian BUMN.

\section{SIMPULAN}

Setelah melaksanakan analisis dan interpretasi data dari hasil wawancara, observasi dan data dokumentasi yang penulis dapatkan dalam melakukan penelitian ini, kemudian penulis membuat simpulan yang sesuai dengan fokus permasalahan penelitian dan tujuan penelitian. Hasil simpulan yang diperoleh oleh penulis dalam melakukan penelitian ini yaitu strategi media relations yang dilakukan oleh PT. Pelabuhan Tanjung Priok dalam menanggapi krisis yang terjadi di Holding Company tersebut yaitu sebagai berikut:

Defensive Strategy (Strategi Difensif), strategi defensif yang dilakukan oleh humas PT. Pelabuhan Tanjung Priok dalam menanggapi krisis yang terjadi pada PT. Pelabuhan Indonesia II (Persero) yaitu dengan menunjukkan beberapa kegiatan positif kepada publik dan memberikan informasi kepada media bahwa PT. Pelabuhan Tanjung Priok merupakan yang tidak identik dengan Holding Company agar citra PT. Pelabuhan Tanjung Priok tidak terpengaruh menjadi negatif karena adanya krisis tersebut.

Selama berlangsungnya krisis tersebut pun strategi yang dibangun oleh PT. Pelabuhan Tanjung Priok yaitu tetap mendidik khalayak mengenai perbedaan
PT. Pelabuhan Indonesia II (Persero) dengan PT. Pelabuhan Tanjung Priok itu sendiri. Namun PT. Pelabuhan Tanjung Priok yang merupakan sebagai salah satu anak PT. Pelabuhan Indonesia II, tetap bertindak untuk mensupport segala arahan yang diperintahkan oleh Holding Company, baik selama krisis terjadi maupun sebelum terjadi. Dengan demikian komunikasi yang terjadi antara Holding Company dan anak perusahaan terutama PT. Pelabuhan Tanjung Priok tetap berjalan dengan lancar dan sesuai aturan dan ketentuan yang telah digariskan oleh perusahaan.

Tahap Pre-Crisis (Tahap Sebelum Krisis), pada tahapan sebelum krisis yang dialami oleh PT. Pelabuhan Indonesia II (Persero) yaitu kondisi yang terjadi di Indonesia Port Company tetap berjalan dengan normal. Namun saat krisis ini mulai menjadi center of news, media langsung mencari tahu kondisi di perusahaan maupun kondisi mobile crane tersebut dengan mendatangi langsung lapangan PT. Pelabuhan Tanjung Priok yang merupakan tempat penyimpanan atau penumpukan mobile crane tersebut. Pada tahap sebelum krisis ini terjadi pun sudah banyak isu yang menimpa pada perusahaan dari pihak eksternal (media dan publik). Oleh karena itu internal perusahaan yaitu para karyawan selalu diminta atau dihimbau untuk tetap fokus bekerja dan seoptimal mungkin dalam melakukan kegiatan ataupun aktivitas dalam bertugas.

Tahap Clean-Up (Tahap Pembersihan), setelah melewati tahap krusial permasalahan yang ada di PT. Pelabuhan Indonesia II (Persero) atau IPC, PT. Pelabuhan Tanjung Priok juga melihat pada tahap pembersihan pemberitaan krisis. Pada tahap ini, tim humas PT. Pelabuhan Tanjung Priok mengeluarkan press release dalam bentuk cetak kepada Forum Wartawan Maritim Indonesia dan dimuat langsung di official website perusahaan (indonesiaport.co.id), dengan adanya pembentukan forum dan pengeluaran press release tersebut ditujukan langsung kepada pihak-pihak yang terkait langsung dengan perusahaan khususnya di bidang kemaritiman.

Adaptive Strategy (Strategi Adaptif), 
tindakan dalam melakukan strategi adaptif iyang dilakukan oleh PT. Pelabuhan Tanjung Priok yaitu perusahaan mengedepankan informasi positif kepada publik yaitu IPC meraih gelar Good Performance Company Dalam Assesmen Kriteria Penilaian Kinerja Unggul dalam agenda akhir tahun 2015 pada 21-27 November 2015. Dari hasil pelaksanaan assesmen IPC mendapatkan skor 479,25 yang menempatkan perusahaan dalam kategori "Good Performance Company".

Namun pada strategi adaptif ini pun PT. Pelabuhan Tanjung Priok tidak melakukan tin-dakan defensive melainkan menahan statement-statement dari internal karyawan perusahaan agar informasi yang dikeluarkan tidak lagi membuat masalah menjadi rumit maupun bertambah lebar. Selain itu pada langkah dalam melakukan strategi ini juga PT. Pelabuhan Indonesia II (Persero) melakukan perubahan struktural direksi yang merupakan pihak yang tersangkut dengan masalah tersebut telah digantikan oleh Pelaksana Tugas Jabatan atau PLT yaitu Dede R. Martin, dan pergantian tersebut dilakukan oleh Menteri Badan Usaha Milik Negara yaitu Rini Soemarno.

Tahap Warning (Tahap Peringatan), kondisi yang terjadi pada IPC dalam tahap krisis merupakan suatu peringatan bagi perusahaan yaitu dengan mengatur terlebih dahulu internal perusahaan dan tetap fokus bekerja secara profesional. Selain itu juga untuk kegiatan hubungan dengan media terkait dengan pemberitaan permasalahan ini, dan perusahaan sebisa mungkin untuk memberikan informasi apa adanya dan tidak ditutupi, juga para internal perusahaan yaitu para karyawan yang berkerja di perusahaan diminta agar menjaga statement di sosial media demi menghindari adanya kesalahpahaman kepada pihak eksternal (media maupun publik). Hal tersebut dilakukan untuk menjaga citra baik perusahaan di mata publik maupun investor.

Tahap Acute (Tahap Akut), pada tahapan krisis akut yang terjadi di perusahaan, terdapat perubahan struktural organisasi yaitu yang merupakan Direktur Utama PT. Pelabuhan Indonesia II (Persero) digantikan oleh Pelaksana Tugas Jabatan atau PLT yaitu
Dede R. Martin, dan pergantian tersebut dilakukan oleh Menteri Badan Usaha Milik Negara yaitu Rini Soemarno. Demikian pemberitaan yang dibuat oleh media pada tahap ini merupakan pemberitaan yang berfokus pada pergantian direksi PT. Pelabuhan Indonesia II (Persero) tersebut.

Dynamic Strategy (Strategi Dinamik), strategi yang dilakukan oleh perusahaan pada strategi dinamik yaitu krisis telah mencapai titik akhir yang merupakan permasalahan pada individu tersebut tidak lagi menjabat di PT. Pelabuhan Indonesia II (Persero) dan bahwa pada strategi hubungan media yang dilakukan oleh perusahaan baik dari PT. Pelabuhan Tanjung Priok maupun Holding Company, tim humas melakukan strategi khusus yang selama ini dibangun yaitu dengan berhubungan baik dengan media secara personal atau antar pribadi dengan wartawan secara langsung, hal tersebut dilakukan demi kelancaran seluruh kegiatan dengan media baik untuk penyebaran informasi maupun klarifikasi permasalahan.

Setelah krisis yang terjadi pada Top Management tersebut, perusahaan tidak lagi menjadi center of news dan tim Humas PT. Pelabuhan Tanjung Priok pun tetap menjaga statement dan lebih tidak menutupi informasi karena permasalahan yang terjadi sudah merupakan ranah hukum. Demikian juga setelah adanya krisis atau per-masalahan yang terjadi pada induk perusahaan tersebut, maka hubungan media dengan perusahaan tetap berjalan dengan baik demi penyampaian informasi yang positif oleh media kepada publik mengenai Indonesia Port Company itu sendiri. Berikut salah satu media yang memberikan positive point terhadap perusahaan setelah adanya pemberitaan yang terfokus pada Direktur Utama R. J. Lino, yaitu media nasional Warta Kota Tribun News memberitakan kegiatan Ekspor Impor Pelabuhan Tanjung Priok berjalan lancar ataupun normal.

Tahap Post-Crisis (Tahap Setelah Krisis), pada tahap terakhir yaitu tahap setelah krisis yang terjadi pada PT. Pelabuhan Indonesia II (Persero) merupakan pemberitaan di media atau pers tidak lagi memusatkan objek tempat atau perusahaan secara langsung melainkan tertuju kepada 
tersangka yang terkait permasalahan tersebut yaitu mantan Direktur Utama PT. Pelabuhan Indonesia II (Persero), R. J. Lino. Oleh karena itu pemberitaan kasus tersebut bukan lagi suatu ancaman bagi perusahaan karena kasus tersebut sudah masuk ke ranah hukum yang merupakan perusahaan tidak dapat berbuat apa-apa selain memperbaiki citra dengan cara bekerja optimal dan profesional sesuai visi-misi perusahaan selama ini.

Kegiatan yang dilakukan oleh Humas PT. Pelabuhan Indonesia II (Persero) dalam tahap ini yaitu mengeluarkan media release yang merupakan sinergi keterbukaan dengan publik maupun pemerintah mengenai kegiatan maupun tindakan yang dilakukan oleh IPC kedepannya.

Bagi Akademis, berdasarkan hasil penelitian ini, penulis merekomendasikan kepada akademis atau peneliti selanjutnya yang akan membahas mengenai strategi media relations dalam menanggapi suatu krisis yaitu untuk lebih meninjau dan meneliti lebih mendalam mengenai pemahaman krisis pada suatu permasalahan yang terjadi pada Holding Company terhadap anak perusahaan atau anak cabang. Kemudian, penulis menyarankan untuk melakukan penelitian lebih mendalam mengenai tahapan krisis dan strategi apa saja yang Humas telah lakukan dalam menanggapi dan menanggulangi krisis yang terjadi pada perusahaan Badan Usaha Milik Negara.

Bagi Praktisi, berdasarkan hasil penelitian ini, penulis merekomendasikan kepada praktisi public relations untuk lebih bersikap responsif dalam menanggapi krisis. Praktisi humas harus memiliki perencanaan maupun prosedur secara tersusun baik dan juga tidak hanya bekerja secara situasional saja. Terkait dengan suatu krisis maupun permasalahan yang terjadi pada perusahaan, humas memiliki peranan penting dalam mencari informasi dan data faktual yang sebenarnya terjadi, maka humas harus berkontribusi dalam perancangan dan penentuan keputusan. Hal ini juga dapat menjadikan humas mengetahui lebih banyak mengenai situasi sebenarnya agar keputusan yang diambil untuk menangani krisis.

Berdasarkan hasil penelitian ini juga dapat dijadikan sebagai masukan untuk perusahaan bahwa masalah yang terjadi pada perusahaan merupakan salah satu krisis yang merupakan dapat menyebabkan suatu krisis kepercayaan dan krisis nama baik perusahaan secara serius. Kemudian, dengan adanya permasalahan yang terjadi secara subyektif tersebut juga dapat mengakibatkan krisis kepercayaan baik dari investor maupun publik.

\section{DAFTAR PUSTAKA}

Huda, L. (2015, 04 November). Pelindo II akan ajukan gugatan pra peradilan. Diakses dari http: //nasional.tempo.co halaman 07871596320 November 2015.

Instagram.@officialportpriok. Diakses dari http: //www.instagram.com/official portpriok 23 Maret 2016

IPC. (2015). Brief book pelindo II: white book IPC. Jakarta: IPC.

Morissan. (2010). Manajemen public relations (edisi pertama, cetakan ke-2). Jakarta: Prenada Media Group.

Mukhtar. (2013). Metode praktis penelitian deskriptif kualitatif (cetakan pertama). Jakarta: Referensi.

Nova, F. (2011). Crisis public relations: strategi pr menghadapi krisis, mengelola isu, membangun citra dan reputasi perusahaan. Jakarta: Gramedia Widiasarana Indonesia.

Official Website IPC. PT. Pelabuhan Indonesia II (Persero). Diakses dari http: //www. indonesiaport.co.id 22 Maret 2016.

Putra, P. M. S. (2016, 08 Januari). Dalami kasus RJ Lino, KPK panggil direktur keuangan PT Pelindo II. Diakses dari http: //www.news.liputan6.com halaman 240725409 Januari 2016.

Rakhmatulloh. (2016, 05 Januari). Kasus RJ Lino, KPK periksa eks direktur Pelindo II. Diakses dari http: //www.nasional. sindonews.com halaman 10745019 Januari 2016.

Saputra, W. \& Nasrullah, R. (2011). Public relations 2.0 teori dan praktik public relations di era cyber. Jakarta: Gramata Publishing.

Suparmo, L. (2011). Crisis management \& public relations mengatasi krisis, memulihkan citra. Jakarta: Indeks Publishing.

Yadin, D. (2003). Public relations - Frank Jefkins disempurnakan oleh Daniel Yadin (Edisi Kelima). Jakarta: Erlangga. 